\title{
Potential of Rapid Anaerobic Fermentation on Animal Slurry for Biogas Production and Storage of Biogas Slurry
}

\author{
Jiawei Liang', Jicui Sun', Athar Mahmood ${ }^{1,2}$, Abdul Basir ${ }^{3}$, \\ Imran Ashraf ${ }^{2}$, Shoujun Yang ${ }^{1 *}$ \\ ${ }^{1}$ Yantai Institute, China Agricultural University, 264670 Yantai, Shandong Province, China \\ ${ }^{2}$ Department of Agronomy, University of Agriculture, Faisalabad, Pakistan \\ ${ }^{3}$ Department of Agriculture, The University of Swabi, Khyber Pakhtunkhwa, Pakistan
}

Received: 4 March 2020

Accepted: 6 April 2020

\begin{abstract}
A study was designed aiming at the degradation of organic matter in liquid phase of pig manure, the inactivation of pathogenic microorganisms and biogas production at different storage temperatures. A low cost rapid anaerobic fermentation, and biogas sewage storage system was constructed. After the four-day anaerobic fermentation, three treatments were set up: the average temperature of spring and autumn $\left(16.1^{\circ} \mathrm{C}\right)$, summer $\left(25^{\circ} \mathrm{C}\right)$, and winter $\left(0.6^{\circ} \mathrm{C}\right)$ in Yantai City was used as storage temperature for 90 days, respectively. The results showed that the biogas potential of anaerobic fermentation and biogas sewage storage at $16.1^{\circ} \mathrm{C}$ and $25^{\circ} \mathrm{C}$ was higher than that stored at $0.6^{\circ} \mathrm{C}$. During the experiment, total solids (TS) and organic matter contents in fecal sewage were decreased with time, and the value was determined at $25^{\circ} \mathrm{C}$. Total phosphorus and potassium contents in biogas sewage did not change significantly over time, but the total nitrogen content decreased. The content of the 5 day biological oxygen demand $\left(\mathrm{BOD}_{5}\right)$, the chemical oxygen demand $\left(\mathrm{COD}_{\mathrm{Cr}}\right)$ and suspended solid concentration (SS) in fecal sewage showed a downward trend over time. The egg mortality of Ascaris lumbricoides increased in different degrees under the three storage conditions. The number of $E$. coli in biogas sewage stored at $0.6^{\circ} \mathrm{C}$ and $16.1^{\circ} \mathrm{C}$ showed a downward trend, and the number of $E$. coli in biogas sewage stored at $25^{\circ} \mathrm{C}$ was significantly higher than at $0.6^{\circ} \mathrm{C}$ and $16.1^{\circ} \mathrm{C}$. The comprehensive analysis showed that at temperature $25^{\circ} \mathrm{C}$, the an-aerobically produced fecal sewage after fermentation had best potential for biogas production.
\end{abstract}

Keywords: anaerobic fermentation, substrate concentration, liquid phase of pig manure, temperature, post storage

*e-mail: sjyang-2008@163.com 


\section{Graphical Abstract}

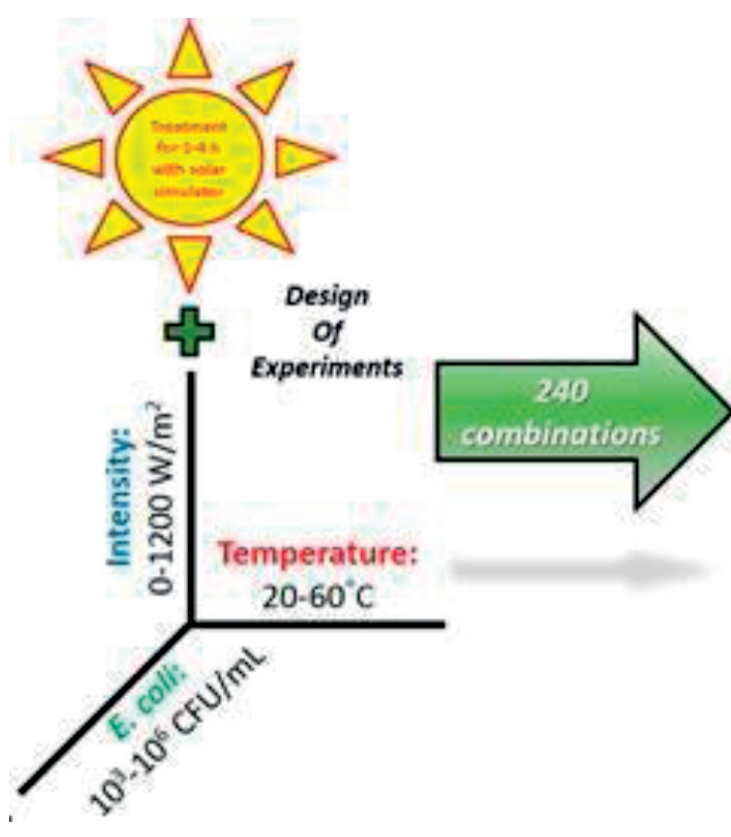

Novelty Statement

The degradation of organic matter in liquid phase of pig manure, the inactivation of pathogenic microorganisms and the development of biogas at different storage temperatures has not yet been reported in the literature. Hence the process of biogas production and biogas sewage storage, the total output of biogas and physico-chemical characteristics of the manure were studied through developing a set of low cost fast and anaerobic fermentation biogas sewage storage system.

\section{Introduction}

In 2011, China raised 471 million pigs. It accounts for about $50 \%$ of the world's pig production [1]. The generation and inappropriate management of animal manure cause serious environmental problems. Animal manure is usually spread on land near confined feeding operations, which leads to a series of problems, such as the contamination of surface water and groundwater with pathogens, odor emission, loss of a potential green energy source, accumulation of excess phosphate $\left(\mathrm{PO}_{4}^{3+}\right)$ in soil, and deterioration of biological ecosystems [2, 3]. Anaerobic digestion technology is regarded as one of the most sustainable technologies due to its low energy consumption, high efficiency and new energy production in the process of treating livestock and poultry wastes [4]. Since China's traditional biogas project anaerobic fermentation gas production and aerobic fermentation fertilizer production are independent of each other, and the cycle of gas production fertilizer production is long, and the quality of organic fertilizer is poor, which affects the efficient operation of the project [5],

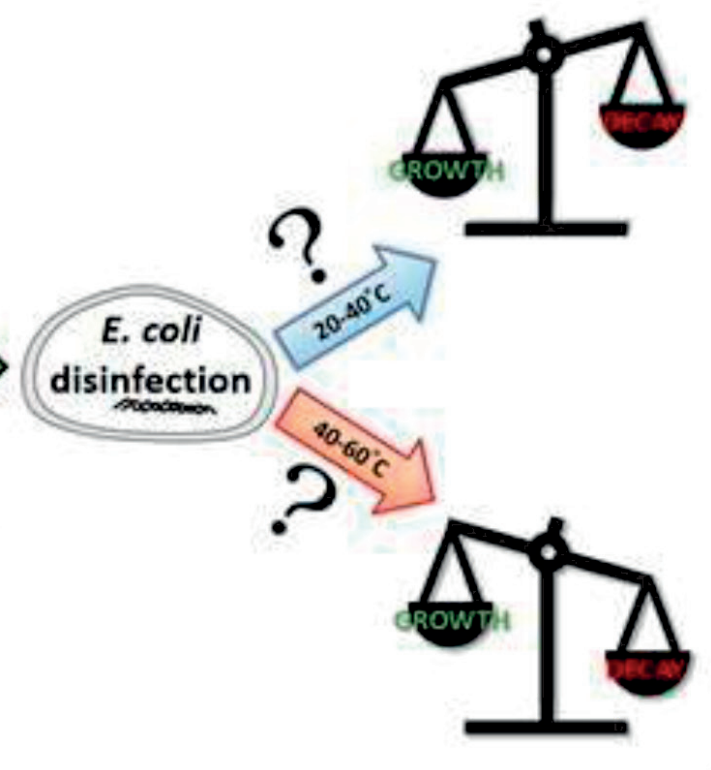

with small farming enterprises and holdings it is quite difficult to popularize the feces treatment of small and medium-sized aquaculture as an enterprise. Therefore, anaerobic fermentation for biogas production is a reliable technology at present. It is of great significance to increase the proportion of this technology in the treatment of livestock and poultry manure in China. The use of biogas technology is very important for nutrient recycling in agriculture [6-7]. The liquid produced along with methane as a result of anaerobic fermentation is rich in organic matter, nitrogen, phosphorus, potassium and some other elements. Moreover, the fermented residues could be used as semi-finished fertilizer. The approaches used for treating the wastewater from farms usually are based on anaerobic digestion. However, further process improvements are still needed to solve the issues associated with biogas residues, which may be more expensive. In general, environmentally sustainable and cost-effective approaches to treat livestock manure would be beneficial for addressing the urgent concerns of surrounding livestock waste [8-9]. Although anaerobic digestion of manure has been achieved in rural Asia, farm-scale factory capital cannot always be offset by biogas production [10-11]. Therefore, developing a low cost rapid anaerobic treatment plants and biogas production is the key to solve the problem of manure treatment and its application to the field as a source of nutrients.

Soft biogas project consists of anaerobic reactor in which impermeable membrane are used to seal the bottom and top of the tank. It has the characteristics of low operation cost, low project cost, high sewage treatment efficiency, and high gas production. In recent years, it has been preferred by livestock and poultry breeding enterprises, especially small and medium-sized aquaculture enterprises. Most 
of the soft biogas engineering systems adopt room temperature fermentation, which often requires a large pool capacity, while most of the conventional biogas engineering systems adopt medium and moderately high temperature fermentation with smaller volume. For safe return of biogas sewage into the field, the retention time of material water conservancy is generally 7 days for fermentation under high temperature and 21 days for fermentation under medium temperature. In both cases, the material hygiene is ensured and fecal pollution is well controlled. On the other hand, when fermentation is done at room temperature, the retention time of the material is prolonged up to $60-90$ days, increasing the interval period for fecal pollution. If the soft biogas project is equipped with heating equipment, it means that the construction and operation costs will be greatly increased. The results of preliminary pre-experiment showed that under the condition of medium temperature fermentation, the biogas production of the material with a total solid concentration of $5 \%$ exceeded $50 \%$ of the biogas potential in 4 days, and then the biogas sewage was stored at room temperature for secondary fermentation, hence reducing the investment cost. During the whole process of biogas production and biogas sewage storage, the total output of biogas and physico-chemical characteristics of the manure were studied. Since the literature has not yet been reported, therefore, liquid phase of pig manure was taken as the research object in this study, aiming at the degradation of organic matter in liquid phase of pig manure, the inactivation of pathogenic microorganisms and the development of biogas at different storage temperatures. This study was conducted on a laboratory scale and the objectives of this study were (1) to construct a low cost rapid anaerobic fermentation and biogas sewage storage system, (2) to provide a scientific basis for fecal sewage treatment and resource utilization in small and mediumsized aquaculture enterprises.

\section{Materials and Methods}

\section{Test Materials}

This experiment started in March 2019 and was conducted at the Biomass Energy Science and Technology Research Center, Yantai Research Institute of China Agricultural University. The feces water (fecal sewage), used in the experiment, was taken from a pig farm in Muping District, Yantai City. After the initial preparations, fecal sewage (raw material) was analyzed for the total solid (TS) content (5\%), organic matter (2.56\%), pH (7.39), suspended solid concentration (SS) $(1447.2 \mathrm{mg} / \mathrm{L})$, the content of the 5 day biological oxygen demand $\left(\mathrm{BOD}_{5}\right)(4734.0 \mathrm{mg} / \mathrm{L})$, the chemical oxygen demand $\left(\mathrm{COD}_{\mathrm{Cr}}\right)(11237.0 \mathrm{mg} / \mathrm{L})$, Escherichia coli population (17000 flu/mL), and mortality of ascaris $\operatorname{egg}(37.5 \%)$.

\section{Experimental Design}

A self-designed rapid anaerobic fermentation and biogas sewage post-storage device (Fig. 1) was used in the experiment. The effective volumes of the anaerobic reactor and biogas sewage storage tank were $20 \mathrm{~L}$ and 520 L, respectively. The film-coated materials were manufactured with high density polyethylene (HDPE) models. In the anaerobic reactor, fermentation was done at medium temperature $\left(30^{\circ} \mathrm{C}\right)$ with retention time of 4 days for water conservancy. In order to accurately simulate the changes in physical and chemical properties of biogas sewage during storage in the Yantai City, Shandong Province, the average temperature of spring and autumn $\left(16.1^{\circ} \mathrm{C}\right)$, summer $\left(25^{\circ} \mathrm{C}\right)$ and winter $\left(0.6^{\circ} \mathrm{C}\right)$ was used as storage temperature for 90 days, respectively.

\section{Methods for Sample Collection and Parameter Determination}

After 4 days of anaerobic fermentation of liquid phase of pig manure, $50 \mathrm{ml}$ biogas sewage sample was collected after every 10 days before the biogas sewage storage, and then after storage, the samples were collected at 60-day interval for the determination of physical and chemical properties of biogas sewage. These properties included TS content, organic matter, $\mathrm{pH}$, total nitrogen, total phosphorus, total potassium, suspended solid concentration (SS), the 5 day biological oxygen demand $\left(\mathrm{BOD}_{5}\right)$, the chemical oxygen demand $\left(\mathrm{COD}_{\mathrm{Cr}}\right)$, Escherichia coli (E.coli ) flora number and Ascaris lumbricoides egg mortality. Duplicate samples for analysis of TS were analyzed following the oven drying method [12]. Total organic carbon (TOC) were determined by the Wet Oxidation Method with $133 \mathrm{mmol} / \mathrm{L} \mathrm{K}_{2} \mathrm{Cr}_{2} \mathrm{O}_{7}$ at $170-180^{\circ} \mathrm{C}$ [13] and $\mathrm{pH}$ was determined with the $\mathrm{pH}$ meter and $\mathrm{pH}$ probe. Total phosphorus was determined by using Model 727 spectrophotometer. Total nitrogen concentrations were determined by the Kjeldahl method (4500-Norg) [14]. For $\mathrm{BOD}_{5}$ determination, a $300 \mathrm{ml}$ airtight bottle, half-filled with saturated oxygen solution (aerated water), was used. One $\mathrm{ml}$ mixed sample was transferred into the bottle, and then the bottle volume was made by the aerated water. The $\mathrm{BOD}_{5}$ was computed from the difference between the initial and final dissolved oxygen concentrations after 5-day incubation under $20 \pm 1^{\circ} \mathrm{C}$. To confirm the $E$. coli in samples, a single colony per sample was randomly selected from a countable plate of each medium type (black colony on XLD agar, blue colony with associated gas on the Petrifilm E. coli/Coliform Count plate) and streaked onto Eosin methylene blue AGAR (EMB). The Eosin methylene blue AGAR plates were incubated for $24 \mathrm{~h}$ at $37^{\circ} \mathrm{C}$. Isolates were confirmed based on Gram stain reaction, cell morphology, and biochemical characterization. Isolation of eggs of intestinal parasites was preceded by loosening its structure by adding 
Table 1. Effect of anaerobic fermentation and storage of biogas sewage on the TS in animal sewage.

\begin{tabular}{|c|c|c|c|c|}
\hline \multicolumn{2}{|c|}{ Treatment } & \multicolumn{3}{|c|}{ TS content $(\%)$} \\
\hline \multicolumn{2}{|c|}{ Raw animal sewage } & \multicolumn{3}{|c|}{5} \\
\hline \multicolumn{2}{|c|}{ Anaerobic fermentation for 4 days } & \multicolumn{3}{|c|}{4.93} \\
\hline \multirow{8}{*}{$\begin{array}{l}\text { Biogas sewage } \\
\text { storage }\end{array}$} & Time (d) & $0.6^{\circ} \mathrm{C}$ & $16.1^{\circ} \mathrm{C}$ & $25^{\circ} \mathrm{C}$ \\
\hline & 10 & $4.93 \mathrm{a}$ & $4.93 a$ & $4.92 \mathrm{a}$ \\
\hline & 20 & $4.93 \mathrm{a}$ & $4.92 \mathrm{a}$ & $4.92 \mathrm{a}$ \\
\hline & 30 & $4.93 \mathrm{a}$ & $4.91 \mathrm{~b}$ & $4.90 \mathrm{~b}$ \\
\hline & 45 & $4.92 \mathrm{a}$ & $4.91 b$ & $4.88 \mathrm{c}$ \\
\hline & 60 & $4.92 \mathrm{a}$ & $4.89 \mathrm{c}$ & $4.84 \mathrm{~d}$ \\
\hline & 75 & $4.91 \mathrm{~b}$ & $4.89 \mathrm{c}$ & $4.82 \mathrm{e}$ \\
\hline & 90 & $4.91 \mathrm{~b}$ & $4.88 \mathrm{c}$ & $4.82 \mathrm{e}$ \\
\hline
\end{tabular}

$1600 \mathrm{ml}$ of a detergent $(0.0025 \%$ Tween- 20 solution $)$ and long-lasting $(4 \mathrm{~h})$ mechanical mixing of a sample of $50 \mathrm{~g}$ of sludge, thereby releasing eggs from the socalled floccules. Subsequently, flotation was used in a high volume of flotation solution $\mathrm{NaNO}_{3}$ with a specific gravity $1.36 \mathrm{~g} / \mathrm{mL}$ (the ratio between the sample mass and water volume was 1:16) followed by centrifugation (2500 $\mathrm{g}$ for $10 \mathrm{~min}$ ). Eggs of the Ascaris spp settled on filters and were confirmed based on microscopic observations (zoom 200X), and followed by periodic observation under a microscope at 3-day intervals for a period of 2 weeks. Eggs with a clear deformation (granulated cytoplasm, damaged sheath, empty sheath) were considered to be dead (non-invasive) [15].

The volume of the biogas was recorded during the process of anaerobic fermentation of the manure and storage of the biogas sewage. Gas production and methane content were determined by Gas Flowmeter MF5700 and PTM-600 portable compound gas analyzer, respectively. The theoretical methane production test of liquid phase of pig manure is based on the fully automatic methane potential test system provided by Hubei Rockek Instrument Co., Ltd.

\section{Statistical Analysis of Data}

Data were statistically analyzed by using Excel 2010 and SPSS 19.0. The least significant difference (LSD) test was used to determine the significant difference among treatment means.

\section{Results}

Table 1 shows that TS content in the liquid phase of pig manure was $0.07 \%$ lower than that in the raw manure after 4 days of anaerobic fermentation at medium temperature $\left(30^{\circ} \mathrm{C}\right)$. During the biogas sewage storage at $0.6^{\circ} \mathrm{C}$, the TS content did not change significantly up till 60-day storage. After 90 days of storage, TS content decreased by $0.02 \%$. While at $16.1^{\circ} \mathrm{C}$ storage, the TS content of biogas sewage did not change in the first 20 day-storage. The TS content decreased significantly by $0.02 \%$ after 30 days and $0.05 \%$ after 90 days. At $25^{\circ} \mathrm{C}$, the decrease rate for TS content was more rapid. The TS contents decreased significantly almost after every 20-day interval. After 75 and 90 days, there was

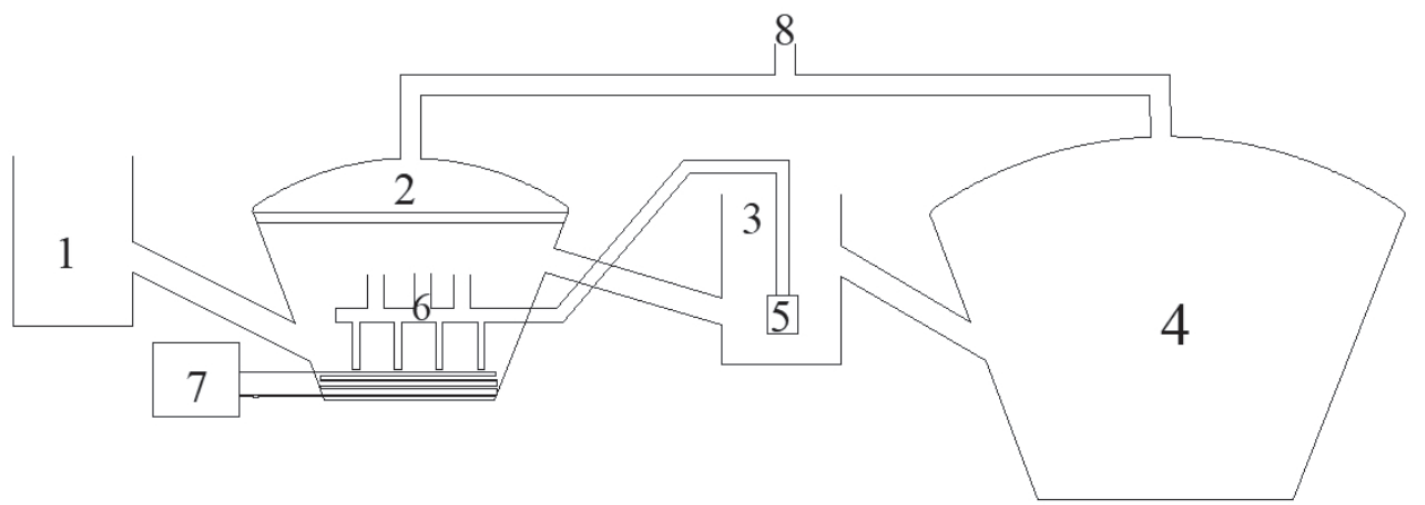

Fig. 1. Schematic diagram of various parts of anaerobic fermentation reactor and biogas sewage storage system. Feed Pool (1), Anaerobic reactor (2), Outfall pool (3), Biogas sewage storage pool (4), High pressure pump (5), Sand removal and shell breaking pipeline (6), Heating equipment (7), and Biogas utilization (8). 


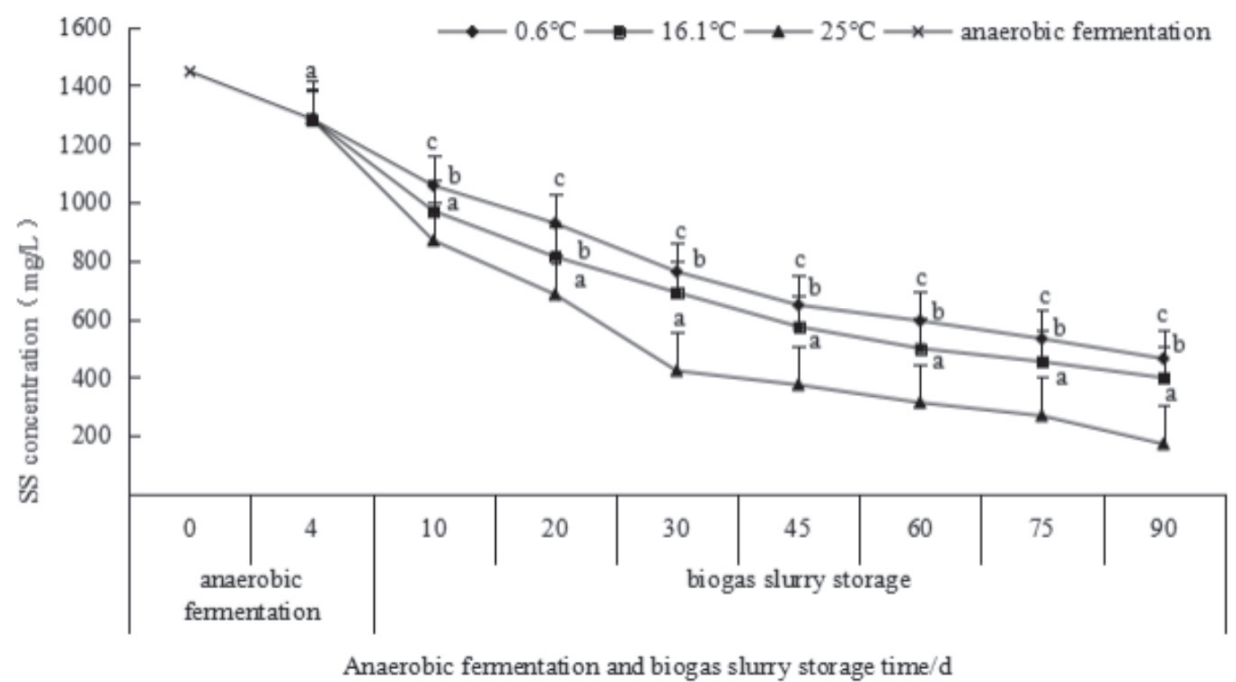

Fig. 2. Effect of anaerobic fermentation and biogas sewage storage on the SS content of biogas sewage.

$0.18 \%$ decrease in the TS content. Data shows that TS content changes during the storage of biogas sewage are inversely related to storage time and temperature.

The SS content in fecal sewage and biogas sewage decreased whether it was fermented or stored after biogas sewage (Fig. 2). The SS content of biogas sewage decreased by $63.9 \%$ and $69.0 \%$ after storage at $0.6^{\circ} \mathrm{C}$ and $16.1^{\circ} \mathrm{C}$ for 90 days, respectively, while the $\mathrm{SS}$ content decreased by $86.7 \%$ after storage at $25^{\circ} \mathrm{C}$ for 90 days, which was 1.36 times and 1.26 times higher than at $0.6^{\circ} \mathrm{C}$ and $16.1^{\circ} \mathrm{C}$, respectively. In case of $\mathrm{SS}$ content also, inverse relationship between the duration and temperature for the biogas sewage was observed.

After 4-day anaerobic fermentation (at $30^{\circ} \mathrm{C}$ ), methane production reached $86.9 \%$ of biogas production capacity (Table 2). When the biogas sewage was stored at $0.6^{\circ} \mathrm{C}$ for 90 days, no biogas was produced, and when the storage temperature raised to $16.1^{\circ} \mathrm{C}$ and $25^{\circ} \mathrm{C}$, the methane production was $7.8 \%$ and $12.1 \%$ of the biogas production capacity, respectively. For the total methane production, the biogas potential of anaerobic fermentation and biogas sewage storage at $0.6^{\circ} \mathrm{C}$ is only $86.9 \%$, while the biogas potential of anaerobic fermentation and biogas sewage storage at $16.1^{\circ} \mathrm{C}$ and $25^{\circ} \mathrm{C}$ is $8.98 \%$ and $13.92 \%$, respectively, higher than when stored at $0.6^{\circ} \mathrm{C}$.
The initial $\mathrm{pH}$ concentration of raw fecal sewage was 7.39 , which reduced to 6.63 after 4 -day fermentation. In the post-storage stage, the variations among $\mathrm{pH}$ were negligible and trends were similar at $0.6^{\circ} \mathrm{C}, 16.1^{\circ} \mathrm{C}$ and $25^{\circ} \mathrm{C}$. The lowest value for the $\mathrm{pH}$ was of 6.29 on the $10^{\text {th }}$ day of storage, while the lowest $\mathrm{pH}$ values at $16.1^{\circ} \mathrm{C}$ and $0.6^{\circ} \mathrm{C}$ were observed on $20^{\text {th }}$ day of storage which were 6.34 and 6.47 , respectively. After storage for 20 to 90 days, the $\mathrm{pH}$ concentrations of biogas sewage at $0.6^{\circ} \mathrm{C}$ and $16.1^{\circ} \mathrm{C}$ remained basically unchanged, while the $\mathrm{pH}$ concentration of biogas sewage at $25^{\circ} \mathrm{C}$ increased gradually at first and reached 6.8 on the $30^{\text {th }}$ day, and then gradually decreased to 6.68 on the $90^{\text {th }}$ day.

The $\mathrm{COD}_{\mathrm{Cr}}$ and $\mathrm{BOD}_{5}$ content of fecal sewage decreased by $2.3 \%$ and $11.2 \%$, respectively (Table 3 ). The $\mathrm{COD}_{\mathrm{Cr}}$ and $\mathrm{BOD}_{5}$ content of biogas sewage stored at $25^{\circ} \mathrm{C}$ decreased by $99.1 \%$ and $99.0 \%$ after 90 days, and at $16.1^{\circ} \mathrm{C}$ decreased by $83.0 \%$ and $87.2 \%$, respectively, and at $0.6^{\circ} \mathrm{C}$ decreased by $82.0 \%$ and $80.8 \%$, respectively. The data showed a positive correlation between storage time and storage temperature for the $\mathrm{COD}_{\mathrm{Cr}}$ and $\mathrm{BOD}_{5}$ content in the biogas sewage.

Total phosphorus and potassium contents in fecal sewage did not change significantly during the whole experimental period (Table 4). After the anaerobic fermentation $\left(25^{\circ} \mathrm{C}\right)$, the total nitrogen content of fecal sewage decreased by $0.02 \%$. During the post-storage

Table 2. Effect of anaerobic fermentation and storage of biogas sewage on the biogas potential of animal sewage.

\begin{tabular}{|c|c|c|c|}
\hline Treatment & $\begin{array}{c}\text { Actual methane production } \\
(\mathrm{mL})\end{array}$ & $\begin{array}{c}\text { Theoretical methane production } \\
(\mathrm{mL})\end{array}$ & Biogas potential $(\%)$ \\
\hline Anaerobic fermentation for 4 days & $6395.2 \mathrm{a}$ & 7359.3 & $86.9 \mathrm{a}$ \\
\hline Biogas sewage storage at $0.6^{\circ} \mathrm{C}$ & $0 \mathrm{~d}$ & 7359.3 & $0 \mathrm{~d}$ \\
\hline Biogas sewage storage at $16.1^{\circ} \mathrm{C}$ & $574.0 \mathrm{c}$ & 7359.3 & $7.8 \mathrm{c}$ \\
\hline Biogas sewage storage at $25^{\circ} \mathrm{C}$ & $890.5 \mathrm{~b}$ & 7359.3 & $12.1 \mathrm{~b}$ \\
\hline
\end{tabular}


Table 3. Effect of anaerobic fermentation and storage of biogas sewage on CODCr and BOD5of biogas sewage.

\begin{tabular}{|c|c|c|c|c|c|c|c|}
\hline \multicolumn{2}{|c|}{ Treatment } & \multicolumn{3}{|c|}{$\mathrm{COD}_{\mathrm{Cr}}(\mathrm{mg} / \mathrm{L})$} & \multicolumn{3}{|c|}{$\mathrm{BOD}_{5}(\mathrm{mg} / \mathrm{L})$} \\
\hline \multicolumn{2}{|c|}{ Raw animal sewage } & \multicolumn{3}{|c|}{11250.0} & \multicolumn{3}{|c|}{4734.0} \\
\hline \multicolumn{2}{|c|}{ Anaerobic fermentation for 4 days } & \multicolumn{3}{|c|}{10994.0} & \multicolumn{3}{|c|}{4205.5} \\
\hline \multirow{8}{*}{ Biogas sewage storage } & Time (d) & $0.6^{\circ} \mathrm{C}$ & $16 .{ }^{\circ} \mathrm{C}$ & $25^{\circ} \mathrm{C}$ & $0.6^{\circ} \mathrm{C}$ & $16.1^{\circ} \mathrm{C}$ & $25^{\circ} \mathrm{C}$ \\
\hline & 10 & $9037.0 \mathrm{a}$ & $8593 a$ & $7987.0 \mathrm{a}$ & $3802.8 \mathrm{c}$ & $3615.9 \mathrm{a}$ & $3360.9 \mathrm{a}$ \\
\hline & 20 & $7837.3 b$ & $6352.4 \mathrm{~b}$ & $5947.0 \mathrm{~b}$ & $3597.9 \mathrm{a}$ & $2873.1 \mathrm{~b}$ & $2502.5 b$ \\
\hline & 30 & $6417.7 \mathrm{c}$ & $4237.6 \mathrm{c}$ & $3643.1 \mathrm{c}$ & $3090.6 \mathrm{bc}$ & $2083.2 \mathrm{c}$ & $1533.0 \mathrm{c}$ \\
\hline & 45 & $5131.4 \mathrm{~cd}$ & $3678.4 \mathrm{c}$ & $2317.4 \mathrm{~d}$ & $2093.6 c$ & $1500.8 \mathrm{c}$ & $945.5 \mathrm{~d}$ \\
\hline & 60 & $4217.3 \mathrm{~d}$ & $2812.5 \mathrm{~cd}$ & $1928.3 d$ & $1720.7 \mathrm{c}$ & $1157.5 \mathrm{~d}$ & $786.7 \mathrm{~d}$ \\
\hline & 75 & $3124.1 \mathrm{~d}$ & $1897.6 \mathrm{~d}$ & $1123.4 \mathrm{e}$ & $1274.6 \mathrm{c}$ & $774.2 d$ & $458.3 \mathrm{e}$ \\
\hline & 90 & $1978.4 \mathrm{e}$ & $1317.5 \mathrm{~d}$ & $100.5 f$ & $807.2 \mathrm{~d}$ & $537.5 \mathrm{e}$ & $41.0 \mathrm{f}$ \\
\hline
\end{tabular}

period, the total nitrogen content of biogas sewage stored at $0.6^{\circ} \mathrm{C}$ decreased by $0.01 \%$, at $16.1^{\circ} \mathrm{C}$ decreased by $0.03 \%$ in 90 days, and at $25^{\circ} \mathrm{C}$ decreased by $0.07 \%$ in 90 days.

The organic matter content of fecal sewage decreased by $0.35 \%$ compared with that of raw fecal sewage (Fig. 4). The organic matter content of biogas sewage stored at $0.6^{\circ} \mathrm{C}, 16.1^{\circ} \mathrm{C}$ and $25^{\circ} \mathrm{C}$ decreased by $0.09 \%, 0.14 \%$ and $0.21 \%$, respectively, after 90 days of storage. The data showed that the change in organic matter content of biogas sewage during post-storage was positively correlated with storage temperature.

As evident from Table 5, the number of E. coli groups increased slightly to $19000 \mathrm{flu} / \mathrm{mL}$ after the anaerobic fermentation (at $30^{\circ} \mathrm{C}$ ). In the post-storage stage, number of $E$. coli were decreased significantly at $0.6^{\circ} \mathrm{C}, 16.1^{\circ} \mathrm{C}$ and $25^{\circ} \mathrm{C}$ after 90 -day storage. The number of $E$. coli increased slightly on the $10^{\text {th }}$ to $30^{\text {th }}$ day after storage at $25^{\circ} \mathrm{C}$, decreased on the $45^{\text {th }}$ to $90^{\text {th }}$ day, and finally decreased to $900 \mathrm{flu} / \mathrm{mL}$. On the $10^{\text {th }}$ day of storage, the egg mortality of Ascaris lumbricoides stored at $25^{\circ} \mathrm{C}$ reached $95.1 \%$, and on the $30^{\text {th }}$ day after storage, the mortality rate of Ascaris lumbricoides eggs was $95.1 \%$. The egg mortality of Ascaris lumbricoides reached up to $95.0 \%$ and $96.1 \%$ at $0.6^{\circ} \mathrm{C}$ and $16.1^{\circ} \mathrm{C}$, respectively.

\section{Discussion}

The $\mathrm{pH}$ concentration of different treatments reached the lowest value on the $10^{\text {th }}$ and $20^{\text {th }}$ day after the start of storage stage (Fig. 3). It might be due to organic acids production during anaerobic digestion, which affected the $\mathrm{pH}$, such as acetate, and that the reaction rate can be obtained by adjusting the $\mathrm{pH}$ [16-19]. Then $\mathrm{pH}$ raised slowly under each treatment condition. This was due to a period of adaptation and cultivation of methanogens occurs later, the acidic products are used for methane formation, and the $\mathrm{pH}$ increases accordingly [20].

Table 4. Effect of anaerobic fermentation and storage of biogas sewage on total nitrogen, total phosphorus and total potassium content of biogas sewage.

\begin{tabular}{|c|c|c|c|c|c|c|c|c|c|c|}
\hline \multicolumn{2}{|c|}{ Treatment } & \multicolumn{3}{|c|}{ Total nitrogen $(\%)$} & \multicolumn{3}{|c|}{ Total phosphorus (\%) } & \multicolumn{3}{|c|}{ Total potassium (\%) } \\
\hline \multicolumn{2}{|c|}{ Raw animal sewage } & \multicolumn{3}{|c|}{0.061} & \multicolumn{3}{|c|}{0.051} & \multicolumn{3}{|c|}{0.052} \\
\hline \multicolumn{2}{|c|}{$\begin{array}{l}\text { Anaerobic fermentation } \\
\text { for } 4 \text { days }\end{array}$} & \multicolumn{3}{|c|}{0.059} & \multicolumn{3}{|c|}{0.050} & \multicolumn{3}{|c|}{0.052} \\
\hline \multirow{8}{*}{$\begin{array}{l}\text { Biogas } \\
\text { sewage } \\
\text { storage }\end{array}$} & Time (d) & $0.6^{\circ} \mathrm{C}$ & $16.1^{\circ} \mathrm{C}$ & $25^{\circ} \mathrm{C}$ & $0.6^{\circ} \mathrm{C}$ & $16.1^{\circ} \mathrm{C}$ & $25^{\circ} \mathrm{C}$ & $0.6^{\circ} \mathrm{C}$ & $16.1^{\circ} \mathrm{C}$ & $25^{\circ} \mathrm{C}$ \\
\hline & 10 & $0.059 \mathrm{a}$ & $0.059 \mathrm{a}$ & $0.059 \mathrm{a}$ & $0.050 \mathrm{a}$ & $0.050 \mathrm{a}$ & $0.050 \mathrm{a}$ & $0.052 \mathrm{a}$ & $0.051 \mathrm{a}$ & $0.050 \mathrm{a}$ \\
\hline & 20 & $0.059 \mathrm{a}$ & $0.058 \mathrm{a}$ & $0.057 \mathrm{~b}$ & $0.050 \mathrm{a}$ & $0.049 \mathrm{a}$ & $0.050 \mathrm{a}$ & $0.052 \mathrm{a}$ & $0.050 \mathrm{a}$ & $0.050 \mathrm{a}$ \\
\hline & 30 & $0.058 \mathrm{a}$ & $0.058 \mathrm{a}$ & $0.056 \mathrm{~b}$ & $0.050 \mathrm{a}$ & $0.049 \mathrm{a}$ & $0.050 \mathrm{a}$ & $0.051 \mathrm{a}$ & $0.050 \mathrm{a}$ & $0.050 \mathrm{a}$ \\
\hline & 45 & $0.058 \mathrm{a}$ & $0.058 \mathrm{a}$ & $0.056 b$ & $0.050 \mathrm{a}$ & $0.049 \mathrm{a}$ & $0.048 b$ & $0.051 \mathrm{a}$ & $0.050 \mathrm{a}$ & $0.050 \mathrm{a}$ \\
\hline & 60 & $0.058 \mathrm{a}$ & $0.057 b$ & $0.055 \mathrm{c}$ & $0.050 \mathrm{a}$ & $0.049 \mathrm{a}$ & $0.048 b$ & $0.051 \mathrm{a}$ & $0.050 \mathrm{a}$ & $0.049 \mathrm{~b}$ \\
\hline & 75 & $0.058 \mathrm{a}$ & $0.056 \mathrm{~b}$ & $0.054 \mathrm{c}$ & $0.050 \mathrm{a}$ & $0.048 b$ & $0.048 b$ & $0.050 \mathrm{~b}$ & $0.050 \mathrm{a}$ & $0.049 b$ \\
\hline & 90 & $0.058 \mathrm{a}$ & $0.056 b$ & $0.052 \mathrm{~d}$ & $0.049 \mathrm{a}$ & $0.048 b$ & $0.048 b$ & $0.050 \mathrm{~b}$ & 0.049 & $0.049 b$ \\
\hline
\end{tabular}




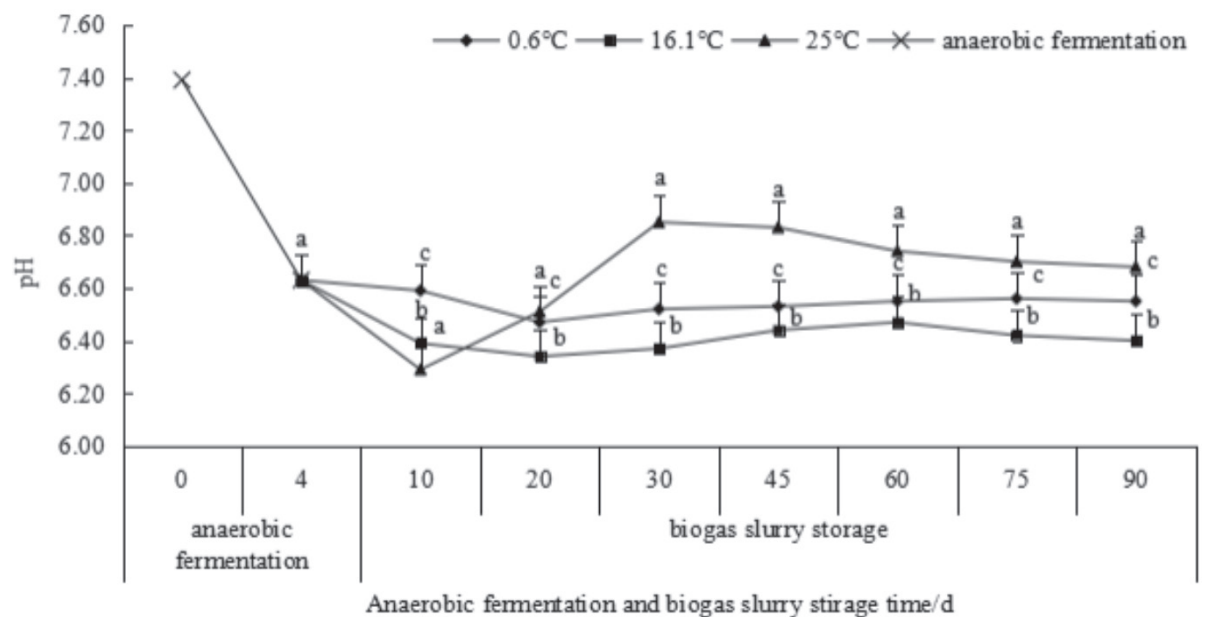

Fig. 3. Effect of anaerobic fermentation and biogas sewage storage on the $\mathrm{pH}$ of biogas sewage.

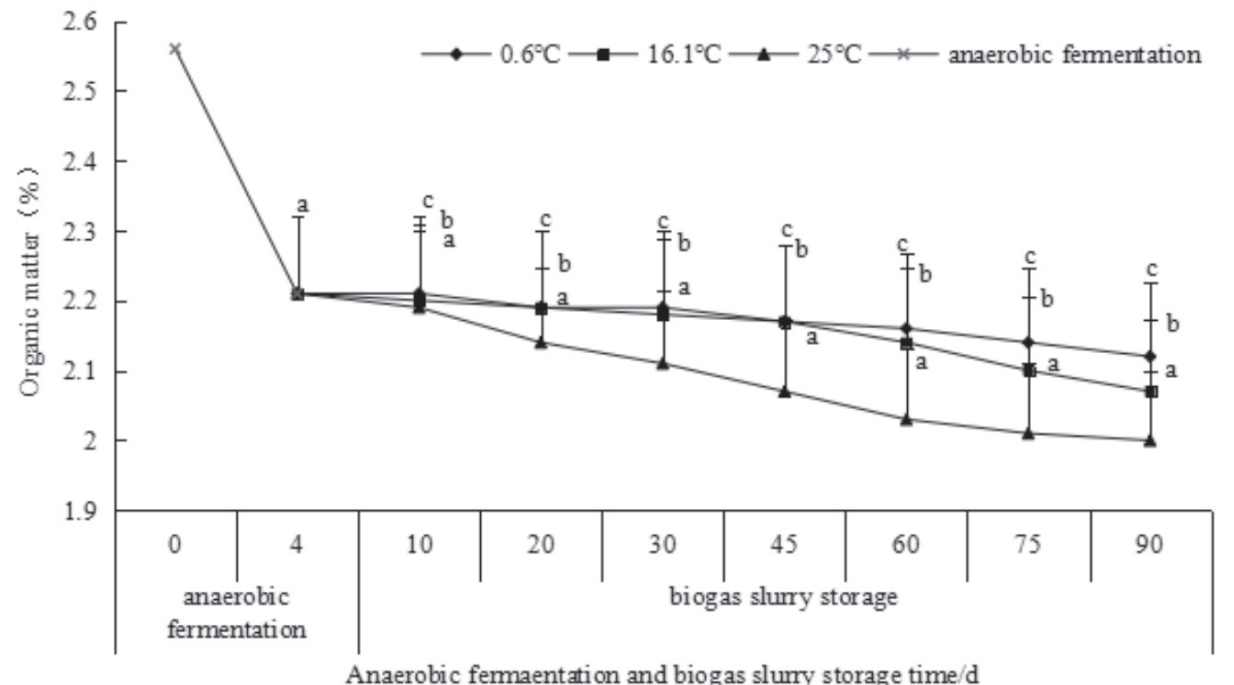

Fig. 4. Effect of anaerobic fermentation and biogas sewage storage on the organic matter of animal sewage.

The downward trend of $\mathrm{COD}_{\mathrm{Cr}}$ and $\mathrm{BOD}_{5}$ concentrations in all treatments (Table 3) were due to nutrients usage by various microbial groups in the fermentation system during anaerobic fermentation and post-storage, and the conversion of fermented microorganisms into some gases by using various nutritional elements in the fermented materials. The $\mathrm{COD}_{\mathrm{Cr}}$ and $\mathrm{BOD}_{5}$ contents in fecal sewage decreased with the fastest rate at $25^{\circ} \mathrm{C}$. The $\mathrm{COD}_{\mathrm{Cr}}$ and $\mathrm{BOD}_{5}$ removal rate may increase with raising temperature within a certain temperature range. The removal rate began to increase with continual increase of temperature, because there were obvious differences in the categories and action of bacteria crowd in the fermentation system under different fermentation temperatures [21]. The decrease of temperature decreased the removal rate of $\mathrm{COD}_{\mathrm{Cr}}$ and $\mathrm{BOD}_{5}[17]$.

Table 4 shows that during the whole experimental period, the content of total nitrogen in biogas sewage showed a downward trend. This might be due to the conversion of some nitrogen into ammonium nitrogen in biogas sewage [22]. However, there was no significant difference in the contents of total phosphorus and potassium in biogas sewage during storage time. This may be due to very low consumption of phosphorus and potassium by methanogens and other microorganisms during the experiment.

The data in Table 1 and Fig. 4 show that the concentrations of organic matter and TS in fecal sewage decreased rapidly during anaerobic fermentation, but there was no significant change in organic matter content in the later-storage stage, which indicated that the organic matter in fecal sewage could produce more methane rapidly in the stage of anaerobic fermentation.

Methane production by anaerobic digestion is generally divided into in four stages: hydrolysis, acid production, acid dehydrogenation and production of methane. Methane $\left(\mathrm{CH}_{4}\right)$ is the main component in 
Table 5. Effect of anaerobic fermentation and storage of biogas sewage on the number of Escherichia coli and the mortality of Ascaris lumbricoides eggs.

\begin{tabular}{|c|c|c|c|c|c|c|c|}
\hline \multicolumn{2}{|c|}{ Treatment } & \multicolumn{3}{|c|}{ The number of Escherichia coli (flu/mL) } & \multicolumn{3}{|c|}{ The mortality of Ascaris lumbricoides eggs (\%) } \\
\hline \multicolumn{2}{|c|}{ Raw animal sewage } & \multicolumn{3}{|c|}{17000} & \multicolumn{3}{|c|}{37.5} \\
\hline \multicolumn{2}{|c|}{ Anaerobic fermentation for 4 days } & \multicolumn{3}{|c|}{19000} & \multicolumn{3}{|c|}{76.8} \\
\hline \multirow{8}{*}{$\begin{array}{l}\text { Biogas sewage } \\
\text { storage }\end{array}$} & Time (d) & $0.6^{\circ} \mathrm{C}$ & $16.1^{\circ} \mathrm{C}$ & $25^{\circ} \mathrm{C}$ & $0.6^{\circ} \mathrm{C}$ & $16.1^{\circ} \mathrm{C}$ & $25^{\circ} \mathrm{C}$ \\
\hline & 10 & $10000 \mathrm{a}$ & $9000 \mathrm{a}$ & $20000 \mathrm{a}$ & $81.3 \mathrm{c}$ & $83.9 \mathrm{c}$ & $90.3 \mathrm{c}$ \\
\hline & 20 & $10000 \mathrm{a}$ & $7000 \mathrm{a}$ & $21000 \mathrm{a}$ & $88.4 \mathrm{c}$ & $94.9 b$ & $95.1 \mathrm{c}$ \\
\hline & 30 & $9000 \mathrm{a}$ & $6000 \mathrm{~b}$ & $22000 \mathrm{a}$ & $95.0 \mathrm{~b}$ & $96.1 \mathrm{a}$ & $97.6 b$ \\
\hline & 45 & $7000 \mathrm{~b}$ & $6000 \mathrm{~b}$ & $15000 \mathrm{~b}$ & $96.4 \mathrm{a}$ & $96.4 \mathrm{a}$ & $97.9 b$ \\
\hline & 60 & $5000 \mathrm{c}$ & $4000 c$ & $9000 \mathrm{c}$ & $96.8 \mathrm{a}$ & $97.1 \mathrm{a}$ & $98.4 \mathrm{a}$ \\
\hline & 75 & $3000 \mathrm{c}$ & $2900 \mathrm{c}$ & $3100 \mathrm{~d}$ & $97.2 \mathrm{a}$ & $97.2 \mathrm{a}$ & $98.5 \mathrm{a}$ \\
\hline & 90 & $1000 \mathrm{~d}$ & $1700 \mathrm{~d}$ & $900 \mathrm{~d}$ & $97.4 \mathrm{a}$ & $97.2 \mathrm{a}$ & $98.9 \mathrm{a}$ \\
\hline
\end{tabular}

gas production, so the concentration of $\mathrm{CH}_{4}$ gradually increases [1]. The factors affecting biogas production by anaerobic fermentation include temperature and $\mathrm{pH}$ [23-26]. The results showed that the biogas potential of anaerobic fermentation and biogas sewage storage at $16.1^{\circ} \mathrm{C}$ and $25^{\circ} \mathrm{C}$ was $8.98 \%$ and $13.92 \%$ higher than that at $0.6^{\circ} \mathrm{C}$, respectively. Fermentation temperature is an important factor affecting anaerobic fermentation. Generally speaking, most methanogens can survive at $10-30^{\circ} \mathrm{C}$. Therefore, under the storage condition of $0.6^{\circ} \mathrm{C}$, methanogens activity was inhibited and it was difficult to produce methane. Biogas sewage stored at $16.1{ }^{\circ} \mathrm{C}$ and $25^{\circ} \mathrm{C}$. There was significant difference in methane content in the gas produced (Table 2), which was due to the good storage conditions available at $25^{\circ} \mathrm{C}$ for rapid decomposition of organic matter, more and more carbon source release, methanogen bacteria had a nice development and reproduction period, the activity of methanogens in biogas sewage is higher, and $\mathrm{CO}_{2}$ produced by microbial respiration in biogas sewage is more converted into methane [27-29].

Fig. 2 shows that under all temperature conditions, the content of SS in fecal sewage showed a downward trend, and the rate of decrease of biogas sewage stored at $25^{\circ} \mathrm{C}$ was higher and decreased by $86.7 \%$ in the later-storage stage. This might be due to the natural deposition of suspended matter in fecal sewage during the test period. In a certain temperature range, high temperature enhances the settling rate of solid particles.

The number of $E$. coli groups were lower in biogas sewage stored at $0.6^{\circ} \mathrm{C}$ and $16.1^{\circ} \mathrm{C}$ than that stored at $25^{\circ} \mathrm{C}$ (Table 5). The number of E. coli in biogas sewage stored at $25^{\circ} \mathrm{C}$ were also higher than that in raw fecal sewage and medium temperature anaerobically fermented biogas sewage. This may be due to spring and autumn $\left(16.1^{\circ} \mathrm{C}\right)$, and winter $\left(0.6^{\circ} \mathrm{C}\right)$ conditions, that were clearly more detrimental to $E$. coli than the summer $\left(25^{\circ} \mathrm{C}\right)$ conditions. Anaerobic fermentation has an effective killing effect on E.coli which is consistent with the research results of Ye [30]. In addition, the inactivation rate of Escherichia coli at high temperature reached $94.3 \%$, higher than that at the medium temperature, which was similar to the findings of Song [31]. Frequent fluctuation of ambient temperature, ca. $0.6^{\circ} \mathrm{C}$, in winter conditions may have caused more rapid bacterial death. During anaerobic fermentation and post-storage, the egg mortality of Ascaris lumbricoides in biogas sewage increased to varying degrees under all the three treatments. The mortality rate of larvae eggs in all samples can reach above 95\%, meeting the standard of innocuous excrement of livestock and poultry. This may be due to the acid produced during the experiment, which inhibits Ascaris eggs.

\section{Conclusion}

The results showed that low cost rapid anaerobic fermentation could be achieved by controlling the total solid concentration of fecal sewage at about 5\% and fermentation at $30^{\circ} \mathrm{C}$. Better gas production effect and harmless treatment effect can be obtained by storing the fermented biogas sewage at $25^{\circ} \mathrm{C}$. Therefore, considering the safety and cost of biogas sewage, this kind of software biogas project can be carried out to solve the current problems arising out of livestock and poultry breeding waste treatment and returning the extracted nutrients back to the field.

\section{Acknowledgements}

This work was supported by the (i) National Key Research and Development Program, Shandong Province (project No. 2016ZDJS11A07 and 2018GNC110021) and (ii) Key Research and Development Program, Yantai (Project No. 2017ZH097), Shandong China. Yantai Education Bureau Subject Development Project 
(2019XDRHXMXK25). We are equally indebted to Yantai Institute, China Agriculture University for providing research facilities.

\section{Conflict of Interest}

The authors declare no conflict of interest.

\section{References}

1. XIN C., DE-YU T., QIAN-WEN S., CHONG L., HONGMIN D. Influence of solid concentration on methane output of anaerobic digestion of swine manure. Chinese journal of agrometeorology, 35 (2), 149, 2014.

2. RAMOS-SUAREZ J.L., RITTER A., GONZALEZ J.M., PEREZ A.C. Biogas from animal manure: a sustainable energy opportunity in the Canary Islands. Renewable and Sustainable Energy Reviews, 104, 137, 2019.

3. ZHANG C., YUAN Q., LU Y.H. Inhibitory effects of ammonia on syntrophic propionate oxiddation in anaerobic digester sludge. Water Research, 146, 275, 2018.

4. HOLM-NIELSEN J.B., SEADI T.A., OLESKOWICZPOPIEL P. The future of anaerobic digestion and biogas utilization. Bioresour Technol, 100 (22), 5478, 2009.

5. JIAN W., YUJUN S., YE L., JINGTAO D., HAIBO M. Variations of carbon and nitrogen during anaerobic-aerobic fermentation for co-production of biogas and organic fertilizer using animal manure and straw. Transactions of the Chinese Society of Agricultural Engineering, 35 (4), 225,2019

6. JAI-CAI Z., RONG-GUI H., MING-GANG L., JIE L., XIN G., DE-SHENG Q. Research progress on innocuous treatment technique of livestock and poultry manure. Journal of Domestic Animal Ecology, 38 (1), 85, 2017.

7. ZHAO L., MENG H., SHEN Y., DING J., ZHANG X. Investigation and development analysis of plantingbreeding circulating agriculture ecosystem system in northern plains in china. Nongye Gongcheng Xuebao/ Transactions of the Chinese Society of Agricultural Engineering, 33 (18), 1, 2017.

8. SHEN Q., SUN H., YAO X.H., WU Y.F., WANG X., CHEN Y., TANG J.W. A comparative study of pig manure waste with different waste straws in an ectopic fermentation system with thermophilic bacteria during the aerobic process:Performance and microbial community dynamics. Bioresource Technology, 281, 202, 2019.

9. GONÇALVES M.R., COSTA J.C., MARQUES I.P., ALVES M.M. Strategies for lipids and phenolics degradation in the anaerobic treatment of olive mill wastewater. Water Research, 46 (6), 1684, 2012.

10. CHEN Y., HU W., FENG Y., SWEENEY S. Status and prospects of rural biogas development in China. Renewable \& Sustainable energy reviews, 39, 679, 2014.

11. CAVINATO C., FATONE F., BOLZONELLA D., PAVAN P. Thermophilic anaerobic co-digestion of cattle manure with agro-wastes and energy crops: comparison of pilot and full scale experiences. Bioresour Technol, 101 (2), 545, 2010.

12. AMERCIAN PUBLIC HEALTH ASSOCIATION, ASSOCIATION, WATER ENVIRONMENT FEDERATION. Standard Methods for the Examination of
Water and Wastewater, twenty Edition. Washington, DC, USA, 1998.

13. GONG W., YAN X., WANG J., HU T., GONG Y. Long-term manure and fertilizer effects on soil organic matter fractions and microbes under a wheat-maize cropping system in northern china. Geoderma, 149 (3-4), 318, 2009.

14. KJELDAHL J. A new method for the determinaton of nitrogen in organic matter. Z.Anal.Chem, 22, 366, 1884.

15. ZDYBEL J., KARAMON J., DĄBROWSKA J., ROZYCKI M., BILSKA-ZAJAC E., KLAPEC T., CENEK T. Parasitological contamination with eggs ascaris spp. trichuris spp. and toxocara spp. of dehydrated municipal sewage sludge in poland. Environmental pollution, 248, 621, 2019.

16. RICO C., GARCÍA H., RICO J.L. Physical-anaerobicchemical process for treatment of dairy cattle manure. Bioresource Technology, 102 (3), 2143, 2010.

17. CYSNEIROS D., BANKS C.J., HEAVEN S., KARATZAS K.A.G. The effect of ph control and 'hydraulic flush' on hydrolysis and volatile fatty acids (vfa) production and profile in anaerobic leach bed reactors digesting a high solids content substrate. Bioresour Technol, 123, 263, 2012.

18. FANTOZZI F., BURATTI C. Anaerobic digestion of mechanically treated ofmsw: experimental data on biogas/methane production and residues characterization. Bioresource Technology, 102 (19), 8885, 2011.

19. ABOUELENIEN F., FUJIWARA W., NAMBA Y., KOSSEVA M., NISHIO N., NAKASHIMADA Y. Improved methane fermentation of chicken manure via ammonia removal by biogas recycle. Bioresource Technology, 101 (16), 6368, 2010.

20. YAO Y., LUO Y., YANG Y., SHENG H., LI X., LI T., SONG Y., ZHANG H., CHEN S., HE W., HE M., REN Y., GAO J., WEI Y., AN L. Water free anaerobic co-digestion of vegetable processing waste with cattle slurry for methane production at high total solid content. Energy, 74, 309, 2014.

21. LILIW., ZHONGJIANGW. Study on the Factors Influencing COD Removal Rate of Cattle Manure Anaerobic Fermentation. Power \& Energy Engineering Conference. IEEE, 2010.

22. ZHIYANG X., MINGXING Z., HENGFENG M., HONGYAN R., ZHENXING H., TAO W., SHUMEI G., WENQUAN R. Analysis of ammonia inhibition on anaerobic digestion via food wastes. Journal of Food Science and Biotechnology. 33 (3), 282, 2014.

23. HANXI W., JIANLING X., LIANXI,. S., XUEJUN L. Effect of addition of biogas slurry for anaerobic fermentation of deer manure on biogas production. Energy. 165, 411, 2018.

24. YUQIU L., DONGYU C., JINYANG L., YONGHUA A., YANQING H., YI L., et al. Experimental study on the effect of temperature and ph value on anaerobic fermentation of pig manure and corn straw. Renewable Energy Resources. 32 (6), 860, 2014.

25. BALDÉ H.,VANDERZAAG A.C., BURTT S.D., WAGNER-RIDDLE C., MACDONALD D.J. Methane emissions from digestate at an agricultural biogas plant. Bioresource Technology, 216, 914, 2016.

26. YU-YING H., JING W., SHI-FENG W., ZHI-PING C., KAI-JUN W., JIAN-E Z. Impact of thermal treatment on biogas production by anaerobic digestion of high-solidcontent swine manure. Environmental Science, 36 (8), 3094, 2015. 
27. FAGBOHUNGBE M.O., ONYERI C.A., SEMPLE K.T. Co-fermentation of whey permeates and cattle slurry using a partitioned up-flow anaerobic digestion tank. Energy. 185, 567, 2019.

28. YIQING Y., HAIYUN L., LING Q., JINGMING S., CHEN S., YAOJING Q., XIUNAN Y., HONG Q., YANG $\mathrm{Y}$. Facilitated methanogenesis involved in anaerobic digestion of dairy manure by soil. Journal of Cleaner Production. 236, 117640, 2019.

29. ZONGQIANG Z., GUANWEN C., YINIAN Z., HONGHU Z., CAICHUN W. The Effects of Different Anaerobic Fermentation Temperature on Biogas Fermentation of Swine Manure. Computer Distributed Control and
Intelligent Environmental Monitoring (CDCIEM), 2011 International Conference on. IEEE Computer Society, 2011.

30. YE X., CHANG Z., QIAN Y., PAN J., ZHU J. Investigation on large and medium scale biogas plants and biological properties of digestate in jiangsu province. Nongye Gongcheng Xuebao/Transactions of the Chinese Society of Agricultural Engineering, 28 (6), 222, 2012.

31. SONG Y.C., KWON S.J., WOO J.H. Mesophilic and thermophilic temperature co-phase anaerobic digestion compared with single-stage mesophilic- and thermophilic digestion of sewage sludge. Water Research, 38 (7), 1653, 2004. 